\title{
Pelatihan Kewirausahaan Berlatar Ekokultural untuk Pemberdayaan Masyarakat Miskin Pedesaan
}

\author{
UYU WAHYUDIN \\ Fakultas Ilmu Pendidikan, Universitas Pendidikan Indonesia, Jl. Setiabudi, Bandung \\ email: udinpls@yahoo.co.id
}

\begin{abstract}
The purpose of this study was to provide an entrepreneurship training model based onthe local culture to empower the rural poor. The goalwas achieved through research and development approach. The results showthat the entrepreneurship training model with an eco-cultural aspect for empowerment of the rural-poorareas should focus on theshaping ofthe public mindset from that of workers to job creators. The substance ofthe material should berelated to ecosystem and cultural elements of the local environment. The images and symbols related to Sundanese's culture were used as media for learning. The curriculum, teaching materials, strategies and the media for training were developed inthis studybased on the theoretical studies and consultation with experts for the empirical effectiveness of empowering the rural poor.
\end{abstract}

Key words: training, entrepreneurship, eco-cultural, the rural poor

\begin{abstract}
Abstrak. Tujuan penelitian ini adalah tersedianya model pelatihan kewirausahaan berlatar budaya lokal untuk pemberdayaan masyarakat miskin di perdesaan. Tujuan itu dicapai melalui pendekatan research and development. Hasil penelitian menunjukkan bahwa model pelatihan kewirausahaan berlatar ekokultural untuk pemberdayaaan masyarakat miskin di perdesaan seyogianya berfokus pada pembentukan pola pikir masyarakat dari pekerja menjadi pencipta pekerjaan. Substansi materi harus terkait dengan ekosistem dan unsur budaya yang lekat dengan masyarakat. Media belajarnya memanfaatkan gambar dan simbol yang terkait dengan budaya Sunda. Kurikulum, bahan ajar, strategi dan media pelatihan sebagaimana dikembangkan dalam penelitian ini berdasarkan hasil kajian teori dan pertimbangan pakar, secara empirik efektif untuk pemberdayaan masyarakat miskin di pedesaan.
\end{abstract}

Kata Kunci: pelatihan, kewirausahaan, ekokultural, kemiskinan.

\section{Pendahuluan}

Bulan September 2000, Indonesia beserta 189 negara anggota Perserikatan Bangsa-Bangsa (PBB) pada Konferensi Tingkat Tinggi Milenium menyepakati Millenium Development Goals (MDGs) yang kemudian dilegalkan dalam Resolusi Majelis Umum PBB Nomor 55/2 tanggal 18 September 2000 tentang $A / R E S / 55 / 2$ United Nations Millennium Declaration. MDGs merupakan paradigma pembangunan global yang menuntut komitmen para pemimpin dunia untuk menangani isu perdamaian, keamanan, pembangunan, hak asasi, dan kebebasan fundamental. Ada delapan arah pembangunan yang disepakati secara global, salah satunya dan yang paling utama menjadi kepedulian dunia adalah penghapusan kemiskinan dan kelaparan berat yang harus dituntaskan pada tahun 2015.

Setelah usaha pencapaian MDGs berjalan lebih sepuluh tahun, populasi penduduk miskin di Indonesia belum berubah secara signifikan. Berdasarkan laporan Badan Pusat Statistik (BPS) tahun 2011.Selama periode Maret 2010-Maret 2011, penduduk miskin di daerah perkotaan berkurang sekitar 0,05 juta orang (dari 11,10 juta orang atau 9,87 persen pada Maret 2010 menjadi 11,05 juta orang atau 9,23 persen pada Maret 2011), sementara di daerah perdesaan berkurang sekitar 0,95 juta orang (dari 19,93 juta orang atau 16,56 persen pada Maret 2010 menjadi 18,97 juta orang atau 15,72 persen pada Maret 2011). Tampak bahwa persentase kemiskinan perdesaan masih lebih besar dari perkotaan.

Telah banyak upaya yang dilakukan pemerintah untuk menanggulangi kemiskinan tersebut. Program penanggulangan kemiskinan paling serius dalam sejarah bangsa Indonesia menurut Mubyarto (2003) adalah program IDT di 
sepertiga desa di Indonesia, dan program Takesra/ Kukesra di dua pertiga desa lainnya. Keduanya didasarkan atas Inpres 5/1993 dan Inpres 3/1996, yang pertama dengan anggaran dari APBN dan yang kedua dari APBN ditambah bantuan "konglomerat". Program IDT maupun Takesra/ Kukesra keduanya dilaksanakan melalui pendekatan kelompok sasaran antara 15-30 kepala keluarga dengan pemberian modal bergulir, yang pertama (IDT) sebagai hibah dan yang kedua sebagai pinjaman/kredit mikro. Saat ini, program tersebut diganti dengan Program Pengembangan Kecamatan (PPK).

Selama tiga dekade, upaya penanggulangan kemiskinan dilakukan dengan penyediaan kebutuhan dasar seperti pangan, pelayanan kesehatan dan pendidikan, perluasan kesempatan kerja, pembangunan pertanian, pemberian dana bergulir melalui sistem kredit, pembangunan prasarana dan pendampingan, penyuluhan sanitasi dan sebagainya. Dari serangkaian cara dan strategi penanggulangan kemiskinan tersebut, semuanya berorentasi material, sehingga keberlanjutannya sangat tergantung pada ketersediaan anggaran dan komitmen pemerintah. Di samping itu, tidak adanya tatanan pemerintahan yang demokratis menyebabkan rendahnya akseptabilitas dan inisiatif masyarakat untuk menanggulangi kemiskinan dengan cara mereka sendiri (Sahdan, 2005).

Ragam program penanggulangan kemiskinan selama ini yang berorientasi material,belum banyak berdampak pada pengurangan penduduk miskin. Hal ini disebabkan antara lain oleh Program Penanggulangan Kemiskinan (PPK) yang kurang mempertimbangkan aspek ekosistem suatu wilayah. Padahal akar kemiskinan banyak disebabkan faktor ekosistem. Kemiskinan yang disebabkan ekosistem sebenarnya masalahnya lebih kompleks dan lebih sulit diatasi. Namun hal ini kurang disadari oleh beragam pelaksana PPK (Namba, 2003).

Sejalan dengan hal tersebut, dalam upaya mencari jawaban atas penyebab kemiskinan, para ilmuwan umumnya melakukan pengkajian fenomena kemiskinan dari dua pendekatan, yaitu pendekatan struktural dan kultural. Menurut pendekatan struktural kemiskinan terjadi akibat sistem pemerintahan yang tidak mendukung terwujudnya ketidakmiskinan. Sedangkan menurut pendekatan kultural kemiskinan muncul akibat masalah mental manusia yang tidak mau maju sehingga mereka tetap hidup di bawah garis kemiskinan. Dilihat dari paradigma pendidikan, upaya pengentasan kemiskinan lebih tepat dihampiri melalui pendekatan kultural. Upaya pemaduan antara kultur dengan pembangunan sejalan dengan agenda UNESCO di mana salah satu bentuknya, populer dengan istilah community cultural development (CCD). Praktek CCD selain mengintroduksikan teknologi yang tepat, peningkatan kelembagaan, dan dukungan pelayanan lain, juga dilakukan dialog kultural. Dialog kultural berguna untuk menciptakan fleksibilitas, pemahaman, dan keinginan untuk saling membantu(Syahyuti, 2007).

Uraian di atas, mengisyaratkan perlunya upaya inovatif untuk mengakselerasi pengentasan kemiskinan selain yang sudah dilakukan selama ini. Karena sumber utama kemiskinan adalah rendahnya kualitas sumberdaya manusia (SDM) yang disebabkan oleh minimnya tingkat pendidikan yang berkualitas dan sikap mental pada sebagian besar masyarakat Indonesia terninabobokan oleh mitos "gemah ripah loh jinawi" dan selalu menunggu untuk disuapi (Fajar, 2009), maka model alternatif pengentasan kemiskinan seyogianya berorientasi nonmaterial dan diawali dengan pembentukan agen pembaharu yang bermental wirausaha sehingga mampu menjadi penggerak pembedayaan masyarakat. Dalam perspektif pendidikan, khususnya Pendidikan Luar Sekolah, untuk membentuk agen pembaharu tersebut antara lain dapat dilakukan melalui pelatihan kewirausahaan. Menurut Lestari (2006) model pelatihan yang berorientasi pada pengembangan jiwa kewirausahaan mampu meningkatkan daya saing masyarakat kalangan bawah. Sehubungan itu, mengembangkan suatu model pelatihan kewirausahaan berlatar pada kondisi ekologis dan budaya lokal -yang dalam penelitian ini disebut dengan terminologi ekokultural - sangat diperlukan untuk meningkatkan pemberdayaan masyarakat miskin di perdesaan. Perhatian terhadap masyarakat miskin perdesaan dipandang penting karena dalam kurun waktu 15 tahun terakhir ini jumlah dan persentase terbesar masyarakat miskin di Indonesia berada di perdesaan (Sahdan, 2005; Azis, 2010; BPS, 2011).Data BPS pada posisi Maret 2011, menunjukkan penduduk miskin di daerah perkotaan sebanyak 11,05 juta orang atau 9,23 persen, sementara di daerah perdesaan adalah 18,97 juta orang 15,72 persen.

Mengacu pada latar belakang seperti dipaparkan di atas, masalah yang dikaji dalam penelitian ini adalah: "Bagaimana model pelatihan kewirausahaan berlatar ekokultural yang efektif untuk pemberdayaan masyarakat miskin perdesaan?" Merujuk pada permasalahannya, tujuan umum penelitian ini adalah tersedianya model pelatihan kewirausahaan berlatar ekokultural yang efektif untuk pemberdayaan masyarakat miskin perdesaan. Sedangkan tujuan khusus yang ingin dicapai dari penelitian ini adalah tersedianya perangkat model pelatihan yang meliputi kurikulum pelatihan, bahan ajar/materi pelatihan, strategi dan media pelatihan bernuansa ekosistem dan budaya lokal yang secara empirik efektif untuk 
pemberdayaan masyarakat miskin perdesaan.

Penelitian ini dalam pelaksanaannya mengikuti prinsip modelresearch and development (R\&D) dari Borg dan Gall (1997) seperti divisualisasikan pada gambar 1.

Rangkaian langkah-langkah kegiatan itu, dirancang melalui dua tahapan penelitian selama dua tahun. Pada tahun I, kegiatan penelitian ini dilakukan untuk: (1) mengkaji kerangka konseptual model pelatihan dan sikap mental kewirausahaan, kemandirian, serta sensitivitas terhadap budaya lokal untuk pengembangan parameter ukur; dan (2) penyusunan model konseptual berupa penyusunan format model awal, instrumen, materi intervensi, kriteria ukur keefektifan model. Penelitian tahap II mencakup kegiatan: (1) validasi model pelatihan berdasarkan pertimbangan pakar dan praktisi; dan (2) revisi model konseptual dalam aspek akademik dan operasional model; (3) melakukan uji coba model; dan (4) penghalusan model terhadap bagian yang secara naratif masih janggal sehingga model tersebut akan lebih halus.

Responden untuk konstruksi model hipotetik pelatihan kewirausahaan adalah tiga pakar dalam bidang pelatihan kewirausahaan, masing-masing dari Entrepreneurship SpecialistILO EAST Project, Prasetiya Mulya Business School, dan Entreuprenership Center Ciputra University.Ketiga lembaga itu dipilih karena memiliki konsep dan pengalaman yang andal dalam pengembangan kewirausahaan. Pandangan para pakar tersebut tentang model pelatihan kewirausahaan dielaborasi dan dipadukan untuk pengembangan model pelatihan pada penelitian ini.

Sementara itu untuk kepentingan uji efektivitas dan fisibilitas penerapan model, respondennya adalahpenduduk miskin Desa Sukamurni di wilayah Kabupaten Garut dan Desa Tenjowaringin di Kabupaten Tasikmalaya. Kedua desa ini dipilih karena: (1) letaknya terpencil sebagai batas paling ujung pada kedua kabupaten tersebut; (2) sebagian besar masyarakatnya petani miskin; (3) tidak pernah tersentuh program pembangunan, baik dari alokasi anggaran Pemenrintah Daerah maupun Pusat; dan (4) posisi geografis kedua desa tersebut berimpit hanya dibelah oleh sungai sebagai pembatasKabupaten Garut dan Kabupaten Tasikmalaya.

Pada masing-masing desa secara acak diambil responden masing-masing 50 orang sehingga total responden menjadi 100 orang. Responden tersebut selanjutnya dikelompokkan secara acak ke dalam kelompok kontrol sebanyak 50 orang dan kelompok eksperimen sebanyak 50 orang.

Data dalam penelitian ini dijaring melalui diskusi kelompok fokus, penyebaran angket, dan observasi.Diskusi kelompok fokus digunakan untuk mengungkap kerangka konseptual model dari para pakar. Penyebaran angket dilakukan untuk

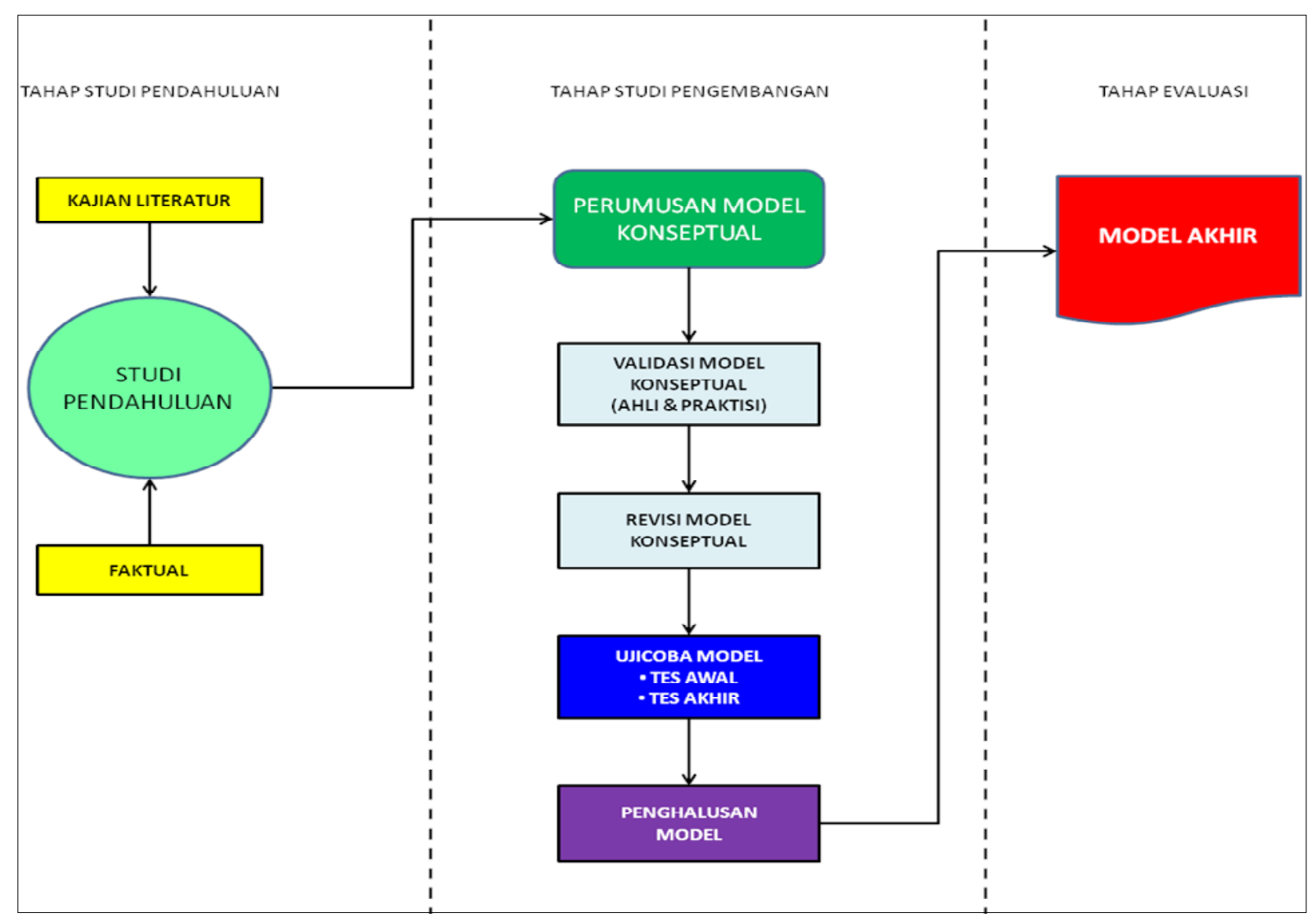

Gambar 1. Alur Pengembangan Model 
mengungkap tingkat keberdayaan masyarakat yang dimanifestasikan dalam sikap mental kewirausahaan, kemandirian, dan sensitivitas terhadap potensi unggulan lokal. Sedangkan observasi dilakukan guna menjaring informasi kinerja model selama ujicoba, terutama berkaitan dengan berbagai permasalahan yang teramati muncul pada saat pelaksanaan uji coba untuk selanjutnya dijadikan umpan balik bagi perbaikan model.

Analisis data dilakukan secara kualitatif maupun kuantitatif. Data kualitatif yang diperoleh melalui diskusi kelompok fokus, berkaitan dengan pengembangan model pelatihan kewirausahaan. Analisis data kualitatif menggunakan empat teknik, yaitu analisis domain, analisis taksonomis, analisis komponensial, dan analisis tema. Tiga analisis data yang disebutkan pertama dilakukan secara simultan pada saat pengumpulan data di lapangan (analisis domain dipergunakan pada tahap eksplorasi menyeluruh, sedangkan analisis taksonomis dan komponensial dipergunakan pada tahap eksplorasi terfokus). Analisis tema dilakukan setelah kegiatan pengumpulan dan analisis data di lapangan. Sementara itu, analisis kuantitatif digunakan untuk menguji efektivitas model digunakan uji perbedaan rata-rata skor gain setiap subjek pada kelompok eksperimen dengan kelompok kontrol

\section{Kemiskinan Perdesaan: Konsep, Indikator, dan Faktor Penyebabnya}

Belum adanya kriteria yang baku dalam mengidentifikasi penduduk miskin, menimbulkan beragamnya pengertian dan kriteria kemiskinan. Kendati demikian, makna kemiskinanantara lain dapat dihampiri dari dua pandangan, yakni kemiskinan material dan nonmaterial. Kemiskinan material menekankan pada ketidakmampuan memenuhi kebutuhan konsumsi dasar, memperbaiki keadaan, dan kurangnya kesempatan berusaha. Sedangkan kemiskinan nonmaterial merujuk kepada pengertian yang lebih luas dari kemiskinan material karena memasukkan aspek sosial dan moral. Kendati demikian, umumnya orang membicarakan kemiskinan mengacu pada kemiskinanan material. Sehubungan itu, Bapenas (Sahdan, 2005) mendefinisikan kemiskinan sebagai kondisi dimana seseorang atau sekelompok orang tidak mampu memenuhi hak-hak dasarnya untuk mempertahankan dan mengembangkan kehidupan yang bermartabat. Hak-hak dasar masyarakat antara lain terpenuhinya kebutuhan pangan, kesehatan, pendidikan, pekerjaan, perumahan, air bersih, pertanahan, sumberdaya alam dan lingkungan hidup, rasa aman dari perlakukan atau ancaman tindak kekerasan dan hak untuk berpartisipasi dalam kehidupan sosial-politik.

Berdasarkan rumusan konkrit indikatorindikator kemiskinan yang dikemukakan Bappenas,
Sahdan (2005) menyimpulkan bahwa indikator utama kemiskinan adalah (1) terbatasnya kecukupan dan mutu pangan; (2) terbatasnya akses dan rendahnya mutu layanan kesehatan; (3) terbatasnya akses dan rendahnya mutu layanan pendidikan; (4) terbatasnya kesempatan kerja dan berusaha; (5) lemahnya perlindungan terhadap aset usaha, dan perbedaan upah;(6) terbatasnya akses layanan perumahan dan sanitasi, (7) terbatasnya akses terhadap air bersih; (8) lemahnya kepastian kepemilikan dan penguasaan tanah; (9) memburuknya kondisi lingkungan hidup dan sumberdaya alam, serta terbatasnya akses masyarakat terhadap sumber daya alam; (10) lemahnya jaminan rasa aman; (11) lemahnya partisipasi; (12) besarnya beban kependudukan yang disebabkan oleh besarnya tanggungan keluarg; (13) tata kelola pemerintahan yang buruk yang menyebabkan inefisiensi dan inefektivitas dalam pelayanan publik, meluasnya korupsi dan rendahnya jaminan sosial terhadap masyarakat.

Berdasarkan data BPS dan Bappenas, sejak tahun 1976 hingga saat ini, ditenggarai bahwa desa di Indonesia tetap menjadi kantong utama kemiskinan (Sahdan, 2005; BPS, 2011). Menurut Azis (2010) - dalam posisinya selaku Ketua Bangar DPR RI - mengungkapkan bahwa besarnya penduduk miskin dan menganggur di wilayah perdesaan, menjadikan sektor pertanian sebagai sektor kunci pembangunan. Produktivitas dan kualitas sektor pertanian adalah dua hal yang harus dibenahi sehingga sektor pertanian menjadi andalan mengatasi kemiskinan dan pengangguran di perdesaan.

Berkenaan dengan penyebabkemiskinan desa, berdasarkan hasil telaahannya terhadap sejumlah literatur, Sahdan (2005) mengungkapkan sebelas faktor utama, yaitu (1) pendidikan yang rendah; (2) ketimpangan kepemilikan lahan dan modal pertanian; (3) ketidakmerataan investasi di sektor pertanian; (4) alokasi anggaran kredit yang terbatas, terbatasnya ketersediaan bahan kebutuhan dasar; (5) kebijakan pembangunan perkotaan (mendorong orang desa ke kota); (6) pengelolaan ekonomi yang masih menggunakan cara tradisional; (7) rendahnya produktivitas dan pembentukan modal; (8) budaya menabung yang belum berkembang di kalangan masyarakat desa; (9) tata pemerintahan yang buruk (bad governance) yang umumnya masih berkembang di daerah perdesaan; (10) tidak adanya jaminan sosial untuk bertahan hidup dan untuk menjaga kelangsungan hidup masyarakat desa; dan (11) rendahnya jaminan kesehatan.

\section{Paradigma Penanggulangan Kemiskinan di Perdesaan}

Upaya yang paling strategis dalam 
penanggulangan kemiskinan menurut Sulekale (2003) yaitu "berikan peluang kepada keluarga miskin dan komunitasnya untuk mengatasi masalah mereka secara mandiri." Ini berarti bahwa pihak luarharus mereposisi peran mereka selama ini, yakni dari agent pemberdayaan menjadi fasilitator pemberdayaan. Input yang berasal dari luar yang masuk dalam proses pemberdayaan masyarakat miskin harus mengacu sepenuhnya pada kebutuhan dan desain aksi yang dibuat oleh keluarga miskin itu sendiri bersama komunitasnya agar sesuai dengan konteks setempat.

$$
\text { Upaya-upaya }
$$

menyeragamkan penanggulangan kemiskinan menurut model tertentu hanya akan menemukan kemungkinan yang lebih besar untuk gagal dalam mencapai sasarannya. Percepatan penanggulangan kemiskinan seyogianya dilakukan dengan mengubah paradigma pemberdayaan masyarakat dari yang bersifat top-down menjadi partisipatif dan bertumpu pada kekuatan serta sumber daya lokal. Penanggulangan kemiskinan yang tidak berlatar komunitas, budaya, dan keluarga miskin itu sendiri, akan sulit berhasil. Dalam kaitan ini, lebih lanjut Sulekale (2003) menyarankan agar program-program penanggulangan kemiskinan ke depan mengarah pada penciptaan lingkungan lokal yang kondusif bagi keluarga miskin bersama komunitasnya dalam menolong diri sendiri. Atas dasar pemikiran tersebut maka upaya penanggulangan kemiskinan masyarakat perdesaan dalam penelitian ini berfokus pada pemberdayaan melalui pelatihan kewirausahaan yang berlatar konteks ekosistem dan budaya masyarakat di mana mereka berada.

\section{Pelatihan kewirausahaan Berlatar Ekokultural untuk Pemberdayaaan Masyarakat Miskin Perdesaan}

\section{Konsep dan Pelatihan Kewirausahaan Berlatar Ekokultural}

Berdasarkan telaahan terhadap rangkuman sejumlah pernyataan ahli ekonomi tentang arti wirausaha, Syahyuti (2007) mengungkapkan bahwa seseorang dapat dikatakan sebagai wirausahawan apabila mempunyai kemampuan melihat dan menilai peluang, mengelola sumber daya yang dibutuhkan serta mengambil tindakan yang tepat, guna memastikan sukses secara berkelanjutan. Namun demikian, perbedaan antara seorang yang memiliki jiwa sebagai seorang wirausaha dengan seorang yang hanya melakukan wirausaha sebagai pekerjaan/hal biasa terletak pada cara dalam membeli, mengolah, menghasilkan dan memasarkan barang/jasa.

Di sisi lain, Timmons (1978) memandang kewirausahaan sebagai tindakan kreatif atau suatu kemampuan melihat dan memanfaatkan peluang, bahkan pada saat semua orang tidak melihat adanya peluang. Dengan demikian, kewirausahaan adalah kesatuan terpadu dari semangat, nilai-nilai, prinsip, sikap, kiat, seni, dan tindakan nyata yang sangat perlu, tepat, dan unggul dalam menangani dan mengembangkan perusahaan atau kegiatan lain, yang mengarah pada pelayanan terbaik kepada pelanggan dan pihak lain yang berkepentingan, termasuk masyarakat, bangsa, dan negara.

Inti dan rahasia kewirausahaan adalah kreativitas dan keinovasian. Kemampuan tersebut menurut Bygrave (Suryana, 2007) merupakan fungsi dari locus of control, pendidikan, pengalaman, nilai-nilai pribadi seperti visi, komitmen, ketidakpuasan, keberanian menghadapi resiko dan lingkungan. Secara epistimologis kewirausahaan berproses diawali karena ada keinginan untuk menolong dirinya sendiri (vision), ketergantungan dan ketidakpastian atau tantangan. Karena ada tantangan maka ada usaha. Sebaliknya tidak ada tantangan maka tidak ada usaha, karena ada tantangan itulah, motivasi berusaha timbul yang kemudian melahirkan proses pencarian alternatif, gagasan, ide dan rencana baru. Kemudian seorang yang berjiwa kewirausahaan memilih alternatif tindakan (innovative) untuk menciptakan nilai keunggulan dan pertumbuhan.

Sifat kepribadian wirausaha perlu dipelajari guna mengetahui karakteristik perorangan yang membedakan seorang wirausaha dan bukan wirausaha. Karakteristik orang-orang yang mempunyai jiwa wirausaha menurut Kuncoro (2000) antara lain: (1) memiliki komitmen dan tekad yang bulat untuk mencurahkan semua perhatiannya pada usaha; (2) memiliki rasa tanggung jawab, baik dalam mengendalikan sumber daya yang digunakan maupun tanggung jawab terhadap keberhasilan wirausaha; (3) selalu berambisi untuk selalu mencari peluang; (4) tahan terhadap risiko dan ketidakpastian; (5) percaya diri, cenderung optimis dan memiliki keyakinan yang kuat terhadap kemampuan yang dimilikinya untuk berhasil; (6) berdaya cipta dan luwes untuk menanggapi perubahan yang cepat dan fleksibel; (7) selalu memerlukan umpan balik yang segera untuk mengetahui hasil dari apa yang dikerjakannya dan selalu belajar dari pengalaman; (8) memiliki tingkat energi yang tinggi, memiliki daya juang yang lebih tinggi dibanding rata-rata orang lainnya; (9) memiliki dorongan untuk selalu unggul melebihi standar yang ada; (10) berorientasi pada masa yang akan datang untuk tumbuh dan berkembang; (11) selalu belajar dari kegagalan, tidak pernah takut gagal dan selalu memfokuskan kemampuannya pada keberhasilan; dan (12) kemampuan dalam kepemimpinan. Ringkasnya, wirausaha yang berhasil memiliki kemampuan taktik mediator dan negosiator yang andal daripada sebagai diktator. 
Ekosistem perdesaaan di Indonesia umumnya merupakan lingkungan pertanian dan peternakan yang dikelola secara tradisional untuk keperluan konsumtif. Dengan demikian, besarnya penduduk masih miskin dan menganggur dan tinggal di wilayah perdesaan, menjadikan sektor pertanian sebagai sektor kunci pembangunan. Dengan mengacu pada pandangan Rostow (Aziz, 2010)bahwa pembangunan ekonomi akan sustainable bila kemajuan industri dan jasa didukung oleh laju sektor pertanian, maka penanggulangan kemiskinan masyarakat perdesaaan tidak bisa lepas dari sektor pertanian yang mampu penyerap lapangan kerja. Seiring dengan hal tersebut, masyarakat juga harus memiliki kemampuan untuk berpartisipasi sebagai tenaga kerja produktif, antara lain melalui pembinaan sikap dan mental kewirausahaan.

Selain faktor ekosistem, dimensi latar budaya juga perlu menjadi kepedulian dalampelatihan untuk membangun jiwa kewirausahaan masyarakat miskin perdesaan. Pelatihan berlatar budaya pada prinsipnya adalah pelatihan yang lekat dengan culture masyarakat yang menjadi sasaran.Sejak 1970an telah timbul diskusi untuk memadukan antara culture dengan development, yang juga menjadi agenda UNESCO. Kesadaran ini datang dari kenyataan bahwa model pembangunan yang diciptakan banyak menghasilkan ketidakpuasan, terutama karena terlalu sempitnya mendefinisikan pembangunan hanya kepada sesuatu yang visual. Pembangunan dapat pula dipandang sebagai sebuah strategi kebudayaan. Disini dilakukan pengembangan budaya melalui berbagai institusi yang ada pada level negara dan masyarakat.

Soedjatmoko (1983) pernah membahas, bahwa pembangunan ekonomi dapat dipandang sebagai masalah. Dalam konteks ini, kebudayaan diartikan sebagai pertautan etika kerja dan nilainilai kerjasama. Menjadikan kebudayaan sebagai kerangka acuan pembangunan ekonomi telah dibahas mendalam dalam ilmu sejarah, antorpologi, dan sosiologi.

Beberapa langkah pendekatan budaya dapat dikemukakan sebagai acuan dalam pelatihan (Syahyuti, 2007). Pertama, penggunaan metode partisipatoris untuk menyerap aspirasi pada tingkat akar rumput, bukan pemimpin formal ataupun informal, dalam survey lapangan. Kedua, menampung aspirasi dari elite lokal, seperti tokoh agama dan adat. Ketiga, penggalian, reinterpretasi, dan revitalisasi "kearifan lokal" yang tersembunyi dalam tradisi lisan dan tulis berkaitan dengan pengembangan lingkungan, infrastruktur, perumahan, tata kota, dan tata desa. Keempat, pembandingan antara aspirasi rakyat dan aspirasi elite lokal. Kelima, penyesuaian rencana ekonomi, teknologi, dan politik dengan aspirasi rakyat dan elite lokal, dan sosialisasinya. Semua langkah tersebut harus didasari dengan metode partisipatoris di lapangan, yang menjadi ujung tombak perencanaan.

\section{Kewirausahaan dan Pemberdayaan Masyarakat Miskin Perdesaan}

Dalam sebuah studi yang dilakukan oleh Hult, et. al., (2003) pada 764 organisasi tentang peran kewirausahaan dalam membangun kultur daya saing mengungkapkan bahwa kewirausahaan memiliki pengaruh tidak langsung terhadap kinerja. Pada studi kasus Koster (2008) yang menganalisis tentang kemungkinan hubungan antara kewirausahaan dan pengembangan ekonomi di India dan negara berkembang lainnya, mengemukakan terdapat hubungan antara jiwa kewirausahaan dengan jumlah kemungkinan terbukanya lapangan kerja baru.

Dalam penelitian ini mengkaji mengani dampak kewirausahaan terhadap pemberdayaan masyarakat miskin perdesaan. Secara spesifik, kewirausaaan dalam kontek penelitian ini berfokus pada jiwa dan sikap mental masyarakat yang dikembangkan melalui pelatihan berlatar ekokultural.

\section{Model Pelatihan Kewirausahaan Berlatar Ekokultural untuk Pemberdayaan Masyarakat Miskin Perdesaan}

\section{Kurikulum dan Materi Pelatihan}

Hasil diskusi kelompok fokus bersama para pakar dari Entrepreneurship SpecialistILO EAST Project, Prasetiya Mulya Business School), Entreuprenership Center Ciputra University, disepakati bahwa pelatihan kewirausahaan mempunyai karakteristik khas, yaitu: (1) tujuannya adalah to be; (2) pembelajaran lewat pengalaman experiential learning; (3) holistik, dalam arti mencakup mask-mindset, attitude, skill, and knowledge; (4) harus menyertakan business creation, business operation and business growth, (5) tidak bisa sekedar diajarkan, tapi harus ditularkan; dan (6) penekanannya dofokuskan pada pembentukan pola pikir. Sehubungan itu, kurikulum model pelatihan kewirausahaan minimal mencakup mata ajar Introduction to entrepreneurship, Creativity in business, Entrepreneurial life skill, Entrepreneurial (project based) learning, dan Principal of entrepreneurship.

Kelima mata ajar pelatihan itu dirancang untuk disajikan dalam waktu lima hari, setiap hari memerlukan waktu minimal delapan jam pelajaran, masing-masing jam pelajaran selama 40 menit.

Selain itu, bahan dan sumber belajar dibuat dan dikembangkan bersama warga masyarakat. Sumber dan bahan belajar tersebut ditemukan dan ditentukan oleh warga masyarakat dengan 
memanfaatkan potensi lokal atau pontensi alam yang ada di sekitar mereka.Untuk mencapai tujuan dan memenuhi cakupan bahan ajar sebagaimana digariskan dalam kurikulum pelatihan serta poptensi lokal masyarakat sasaran yang umumnya daerah agraris, maka materi pelatihan juga perlu dilengkapi dengan: (1) keterampilan bertani dan beternak; (2) prospek dan pengembangan agrobisnis; dan (3) pengembangan koperasi dalam mendukung pertanian. Alokasi waktu yang diperlukan untuk ketiga materi tersebut adalah tiga hari.Mengingat bahwa model pelatihan kewirausahaan yang dikembangkan dalam penelitian ini adalah berlatarekosistem dan budaya lokal, maka ramuan materi untuk kelima bahan ajar yang disajikan dalam kurun waktu lima hari it

\section{Strategi, Metode, dan Media Pelatihan}

Perilaku wirausaha dibentuk oleh tiga faktor, yaitu bawaan sejak lahir, lingkungan, dan latihan. Dari ketiga faktor itu, perilaku wirausaha lebih dibentuk oleh latihan. Strategi mengajarkannya dilakukan melalui sebuah sharing kepada entrepreneurship educators yang terbuka untuk diperkaya dan dikritisi. Pendidiknya harus memiliki kompetensi dalam bidang pelatihan dan pendidikan kewirausahaan serta memiliki business entrepreneurial experience yang memadai.

Sementara itu, metode yang digunakan dalam pelaksanaan pelatihan bisa sangat bervariasi sebagaimana pada gambar 2 .

Masyarakat sasaran pelatihan kewirausahaan ini umumnya adalah orang dewasa. Dengan mengacu pada beberapa konsep dari beberapa tokoh yang mengembangkan pemahaman tentang pendidikan orang dewasa maka dapat dirumuskan dalam beberapa sudut pandang, antara lain:(1) waktu, berlangsung kapan saja, sepanjang hidup, setelah matang atau dewasa dengan mandiri atau independen; (2) tempat dimana saja, tidak diikat oleh ruang tetentu dan disesuaikan dengan kebutuhan; (3) tujuan, sesuai orientasi belajar dari warga belajar tersebut; (4) materi pelajaran, apa saja sesuai dengan kebutuhan warga belajar; (5) aktivitas belajar, disesuaikan dengan pengalaman warga belajar; (6) pendidik: bukan guru tetapi fasilitator yang memahami karakter, filsafat kerja dan keinginan membantu warga belajar; dan (7) metode, demokratis, terbuka, saling menghargai dan berbagi pengalaman.

Media pelatihan yang digunakan adalah lebih banyak menggunakan gambar dan simbol-simbol sehingga lebih mudah dicerna oleh warga masyarakat, termasuk mereka yang buta aksara. Dengan demikian, modul-modul pelatihan pun diperkaya dengan ilustrasi dari penjelaan verbal yang dipaparkan. Gambar yang digunakan sedapat mungkin bersumber dari lingkungan dan lambang budaya yang melekat pada masyarakat sebagaimana dapat diungkap dengan instrumen kelekatan budaya, dalam hal ini budaya Sunda.

\section{Parameter Ukur Keberdayaan Masyarakat}

Keberdayaan masyarakat dalam penelitian ini diukur melalui variabel sikap mental kewirausahaan dan kemandirian. Dalam penelitian ini dikembangkan kuesioner yang terdiri atas 69 butir penyataan. Jawaban responden dinyatakan dalam tingkat kesesuaian responden dengan yang dinyatakan dalam pernyataan yang bersangkutan.

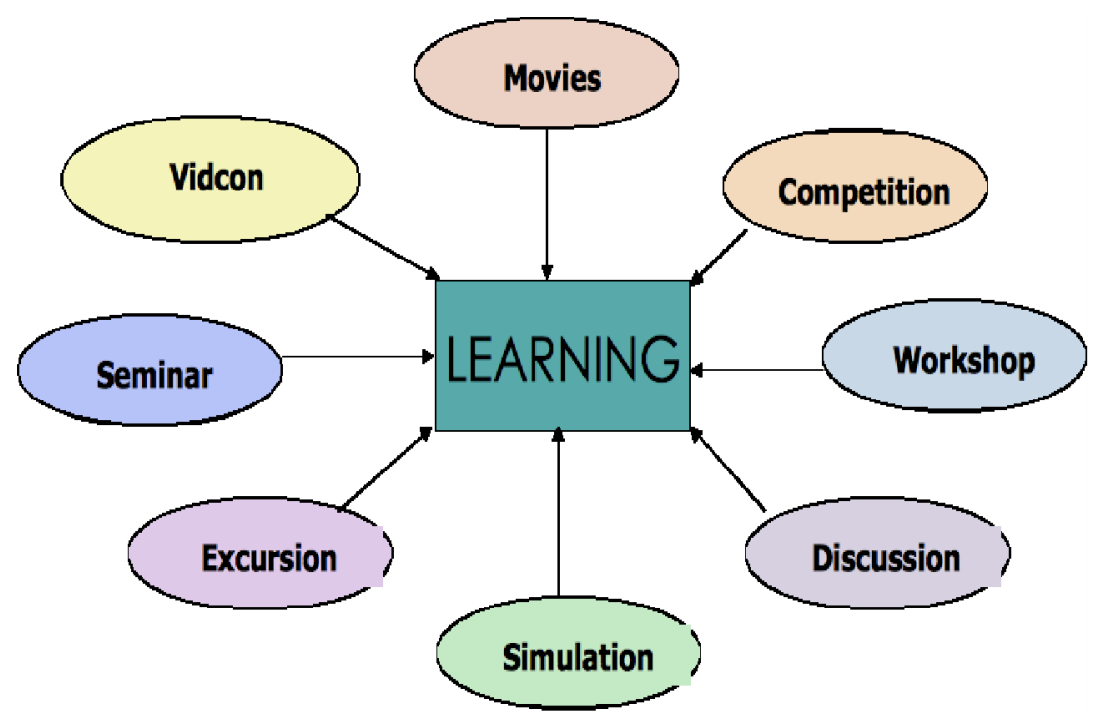

Gambar 2

Ragam Metode Pelatihan 
Tingkat kesesuaian itu merentang dari 1 sampai dengan 7. Sebelum digunakan dalam penelitian, kuesioner ini terlebih dahulu diujicobakan kepada 80 orang warga masyarakat yang menjadi sasaran penelitian, yakni Desa Tenjowaringin di Tasikmalaya dan Desa Sukamaju di Kabupaten Garut yang tidak menjadi rerponden pada kepompok kontrol dan eksperimen. Dari 80 lembaran jawaban yang terkumpul, 71 di antaranya memadai untuk dianalisis lebih lanjut. Sedangkan 9 lembar jawaban lainnya tidak disertakan dalam proses analisis karena jawabannya tidak lengkap. Uji coba ini dimaksudkan untuk menguji validitas setiap butir pernyataan dan menghitung koefisien reliabilitas perangkat kuesioner. Uji validitas butir pernyataan dilakukan dengan cara mengkorelasikan skor masing-masing butir pernyataan yang diperoleh setiap responden dengan skor total yang diperoleh responden yang bersangkutan. Koefisien korelasi dihitung dengan menggunakan rumus rank order correlation. Proses perhitungannya dilakukan dengan mengoperasikan perangkat lunak SPSS.

Hasil uji coba menunjukkan bahwa dari 69 butir pernyataan yang diuji validitasnya, ada 58 pernyataan yang memiliki koefisien korelasi yang signifikan pada á $<0.05$. Koefisien korelasinya merentang dari 0,213 sampai dengan 0,899. Dengan demikian, ke-58 butir pernyataan itu dinyatakan valid. Selanjutnya, secara keseluruhan ke-58 butir pernyataan itu dihitung koefisien reliabilitasnya dengan menggunakan teknik Alfa Cronbach diperoleh koefisien reliabilitas sebesar 0,935 signifikan pada á < 0.05 . Berdasarkan hasil uji validitas butir pernyataan dan perhitungan koefisien reliabilitas keseluruhan perangkat kuesioner sebagaimana dikemukakan di atas, dapat dinyatakan bahwa kuesioner pengungkap data keberdayaan masyarakat, layak digunakan dalam penelitian.

\section{Hasil Uji Efektivitas Model}

Uji efektivitas model dilakukan melalui eksperimen semu dengan menggunakan desain "Kelompok Kontrol Tak-Setara," masing-masing kelompok sebanyak 50 orang. Masyarakat di Desa
Sukamurni Kecamatan Cilawu Kabupaten Garut diposisikan sebagai kelompok eksperimen sedangkan masyarakat di Desa Tenjowaringin Kecamatan Salawu Kabupaten Tasikmalaya diposisikan sebagai kelompok kontrol, dengan harapan dapat mengurangi efek interaksi antara kelompok eksperimen dan kelompok kontrol.

Hasil analisis data deskriptif terhadap kelompok eksperimen $(n=48)$ dan kelompok kontrol $(n=42)$, diperoleh harga-harga statistik pada tabel 1.

Untuk kepentingan uji efektivitas model yang dipertimbangkan adalah skor gain. Uji efektivitas model dilakukan melalui uji perbedaan rata-rata skor gain skor post test dan pre test antara kelompok eksperimen dengan kontrol.

Hasil uji homogenitas varian menghasilkan harga $F$ sebesar 0,810 dan $p=0,371$. Dengan demikian varian kedua kelompok tersebut homogen. Sementara itu, hasil uji perbedaan dua rata-rata skor gainmenunjukkan harga $t=8,607$ dan harga $p=0,000$. Tampak bahwa harga $p$ jauh lebih kecil dari 0,05 sehingga perbedaan tersebut secara statistik signifikan. Rata-rata keberdayaan kelompok warga masyarakat miskin yang mengikuti pelatihan kewirausahaan berlatar ekokultural (eksperimen) lebih tinggi dibanding kelompok yang tidak dilatih (kontrol). Dari hasil pengujian itu dapat diungkapkan bahwa model pelatihan kewirausahaan berlatar ekokultural yang dikembangkan dalam penelitian ini, secara empirik dapat meningkatkan kemandirian warga belajar.

Keberdayaan masyarakat miskin dalam penelitian ini mencakup kemandirian psikologis dan sikap mental kewirausahaan. Kemandirian psikologis diartikan sebagai kesiapan dan kemampuan warga belajar untuk melepaskan diri dari ikatan emosi dengan orang dewasa lain dalam mengatur, mengurus, dan menyelesaikan persoalan-persoalannya sendiri dan seberapa jauh kemampuan mereka dalam mengambil keputusan dan melaksanakannya melalui perbuatan atau tindakan nyata, serta kemampuan untuk melawan/ menolak tekanan atau tuntutan orang lain berdasarkan prinsip benar dan salah, atau penting

Tabel 3

Harga-harga Statistik Keberdayaan Kelompok Eksperimen dan Kontrol Sebelum dan Sesudah Perlakuan

\begin{tabular}{|c|c|c|c|c|}
\hline \multirow{2}{*}{ Kelompok } & \multicolumn{2}{|c|}{ Kelompok Eksperimen } & \multicolumn{2}{c|}{ Kelompok Kontrol } \\
\cline { 2 - 5 } & Rata-rata & Simpangan Baku & Rata-rata & Simpangan Baku \\
\hline Pre Test & 136,46 & 26,131 & 140,76 & 43,634 \\
\hline Post Test & 217,88 & 29,740 & 154,24 & 40,182 \\
\hline Gain & 81,42 & 10,198 & 30,21 & 46,750 \\
\hline
\end{tabular}


dan tidak penting. Makna kemandirian psikologis mencakup tiga aspek, yaitu kemandirian emosi (emotional autonomy), kemandirian bertindak atau berperilaku (behavioral autonomy) dan kemandirian nilai (values autonomy).

Kemandirian emosi menunjuk pada aspek kemandirian yang berkaitan dengan kebebasan dari ketergantungan. Subdimensi dan indikator kemandirian emosi sebagai berikut: (1) mampu membangun pandangan de-idealized terhadap orang tua/orang yang dituakan (tidak mengidealkan orang tuanya/orang yang dituakan); warga belajar tidak lagi melihat orang tua/orang yang dituakan mereka sebagai figur yang mengetahui segalanya (all knowing) atau menguasai segalanya (all powerfull); (2) mampu memandang orang tua/orang dewasa lainnya sebagaimana orang biasa pada umumnya (parents as people); warga belajar mampu melihat (kedudukan/fungsi dan peran) dan berinteraksi dengan orang tua sebagaimana orang lain pada umumnya dan bukan hanya sebagai orang tua mereka; (3) nondependency (ketidaktergantungan); warga belajar memiliki tingkat kemampuan untuk lebih bersandar pada kekuatan diri sendiri daripada bergantung pada bantuan orang tua/ orang dewasa lain ketika mereka mengalami ketakutan, kebingungan, atau kesedihan, dan (4) individuated (berdiri sendiri); warga belajar merasa berdiri sendiri dalam berhubungan dengan orang tua mereka; siswa memiliki kehidupan pribadi yang tidak selalu harus diketahui oleh orang tua/orang dewasa lainnya.

Kemandirian perilaku menunjuk pada kemampuan untuk membuat keputusan-keputusan secara bebas dan menindaklanjuti sendiri keputusan keputusan tersebut tanpa terlalu bergantung pada bantuan/bimbingan orang lain. Subdimensi dan indikator dari kemandirian perilaku adalah sebagai berikut: (1) kemampuan mengambil keputusan (decision making abilities): warga belajar mampu berpikir hipotetis dalam membuat keputusan sendiri dan mengetahui secara tepat kapan harus meminta saran atau pendapat orang lain; (2) keteguhan terhadap pengaruh pihak lain (conformity and susceptability to influence): warga belajar memiliki keteguhan dalam pendirian dan bersikap terhadap pengaruh dan tekanan dari orang lain; dan (3) kepercayaan diri (self reliance): warga belajar mampu membuat keputusan dengan mengandalkan kepercayaan pada diri mereka sendiri.

Kemandirian nilai menunjuk pada kemampuan untuk melawan/menolak tekanantekanan atau tuntutan-tuntutan orang lain; dalam arti, memiliki seperangkat prinsip tentang benar dan salah, tentang penting atau tidak penting. Subdimensi dan indikatornya mencakup hal-hal berikut: (1) abstract belief: warga belajar memiliki keyakinan-keyakinan yang lebih jauh dan mendalam terhadap segala sesuatu; (2) principled belief: Warga belajar memiliki keyakinankeyakinan yang semakin berakar pada prinsipprinsip umum yang memiliki dasar ideologi; (3) independent belief: Warga belajar memiliki keyakinan-keyakinan yang tertanam atas kesadaran dan nilai-nilai yang mereka miliki sendiri tanpa pengaruh dari figur otoritas.

Sementara itu sikap mental kewirausahaan meliputi rasa percaya diri, berorientasi tugas dan hasil, pengambilan resiko, kepemimpinan, keorisinilan, berorientasi ke masa depan. Rasa percaya diri tampak dalam keyakinan, ketidaktergantungan, individualitas, dan optimisme. Berorientasi tugas dan hasil tampak dalam kebutuhan akan prestasi, berorientasi pada nilai keuntungan secara ekonomis, ketekunan dan ketabahan tekad kerja keras, dan mempunyai dorongan kuat, enerjik dan inisiatif. Pengambilan resiko tampak dalam kemampuan mengambil resiko dan suka pada tantangan. Kepemimpinan tampak dalam bertingkah laku sebagai pemimpin, dapat bergaul dengan orang lain, dan menanggapi saran dan kritik. Keorisinilan tampak dalam inovatif dan kreatif, fleksibel, serba bisa, dan mengetahui banyak hal. Sedangkan berorientasi ke masa depan mengacu pada pandangan yang luas ke masa depan.

\section{Simpulan dan Saran}

Model pelatihan kewirausahaan berlatarekokultural untuk meningkatkan daya saing masyarakat miskin di perdesaan seyogianya berfokus pada perubahan dan pembentukan pola pikir dari pekerja menjadi pencipta pekerjaan. Substansi materi pelatihan harus terkait dengan unsur-unsur budaya yang lekat terhadap warga masyarakat dan bebasis pada agro bisnis mengingat lokasi ekologis penelitian ini berada pada daerah agraris dengan mata pencaharian utama penduduknya bertani. Media belajarnya lebih banyak memanfaatkan gambar dan simbol-simbol yang terkait dengan budaya Sunda sehingga mudah dipahami oleh warga masyarakat termasuk mereka yang tidak bisa baca-tulis. Model alat ukur keberdayaan masyarakat yang mencakup kemandirian, sikap mental kewirausahaan, telah teruji secara rasional maupun empirik. Alat ukur ini dapat dijadikan instrumen untuk mengungkap kebutuhan pelatihan serta data dasar pengembangan materi pelatihan kewirausahaan berlatar ekokultural.

Model pelatihan kewirausahaan berlatarekokultural secara efektif dapat meningkatkan keberdayaan masyarakat miskin di perdesaan. Keberdayaanini tampak dalam sikap mental kewirausahaan dan kemandirian. 
Keberdayaan masyarakat miskin di perdesaan akan bertambah kuat dengan cara menciptakan perubahan kreatif yang berarti dari tidak bernilai menjadi bernilai, menghasilkan sebuah produk akhir yangmemiliki nilai pasar, mampu memulai dari nol dan yang dianggap tidak berharga.

Model pelatihan kewirausahaan berlatar ekokultural yang meliputi kurikulum, bahan ajar/ materi pelatihan, strategi dan media pelatihan untuk pemberdayaan masyarakat miskin di perdesaan sebagaimana dikembangkan berdasarkan hasil kajian teori dan pendapat para pakar serta teruji secara empirik dalam penelitian ini, dapat diadaptasi dan diterapkan di lain tempat dengan penyesuaian ekologi dan kultur setempat. Agar model pelatihan yang dihasilkan bersifat utuh maka perlu dilakukan penataan struktur model dan penyempurnaan unsur-unsurnya, mulai dari dasar pemikiran hingga model evaluasi programnya.

Parameter ukur keberdayaan masyarakat yang dihasilkan dalam penelitian ini dapat dijadikan instrumen untuk mengungkap data yang akan dijadikan dasar analisis kebutuhan pelatihan dan sebagai pijakan dalam pengembangan bahan ajar dan media pembelajaran.Perlu mengembangkan bahan ajar dan materi pelatihan yang sarat dengan ilustrasi gambar dan simbol yang memperjelas narasi verbal. Gambar dan simbol ini harus dipilih sehingga sangat lekat dengan unsur-unsur ekologis dan budayan lokal.

\section{Daftar Pustaka}

Biro Pusat Statistik. (2011). "Profil Kemiskinan di Indonesia Maret 2011: Jumlah Penduduk Miskin Maret 2011 Sebanyak 30,02 Juta Orang". Berita Resmi Statistik. No. 45/07/Th. XIV, 1 Juli 2011.

Borg and Gall (1997), Education Research, An Introduction, New York \& London: Longman Inc.

Hult, J.. et al. (2003). The Role of Entrepreneurship in Building Cultural Competitiveness in Different Organizational Types. Journal of Management. 29 (3). 401-426.

Koster, S \& Rai, S.K. (2008). Entrepreneurship and Economic Development in A Developing Country: A Case Study of India. Journal of Entre- preneurship. 17 (2). 117-137.

Lestari, H.S. (2006). Kajian Model Unit Usaha Baru. Evaluasi dan pelaporan Peneliti pada Deputi Bidang Pengkajian Sumber Daya UKMK.

Mubyarto. (2003)."Penanggulangan Kemiskinan di Indonesia" Jurnal Ekonomi Rakyat Th. II - No. 2 - April 2003. Tersedia di http:// www.ekonomirakyat.org/edisi_14/ artikel_4.htm

Namba, A. (2003). "Pendekatan Ekosistem Dalam Penanggulangan Kemiskinan: Refleksi Penanggulangan Kemiskinan Di Sulawesi Tengah". Jurnal Ekonomi Rakyat Th.IINo. 1 Maret 2003. Tersedia di http:// www.ekonomirakyat.org/edisi_14/ artikel_4.htm.

Sahdan, G. (2005). "Menanggulangi Kemiskinan Desa". Jurnal Ekonomi Rakyat Th.IINo. 2 Maret 2005. Tersedia di http:// www.ekonomirakyat.org/edisi_22/ artikel_6.htm

Sulekale, D. D. (2003). "Pemberdayaan Masyarakat Miskin di Era Otonomi Daerah".Jurnal Ekonomi Rakyat Th.IINo. 2April 2003. Tersedia di http:/ /www.ekonomirakyat.org/edisi_14/ artikel_4.htm

Sonhaji. (2006). Budaya Kemiskinan: Studi Penjajagan atas Kegiatan Meminta-minta Kelompok Pengemis Mingguan di Surakarta. Jurnal Spirit Publik. 2 (1), 37-50.

Suryana. (2007). Upaya Menggali Keunggulan Berkelanjutan melalui Manajemen Entrepreneurship. Pidato Pengukuhan Jabatan Guru Besar UPI. Bandung: Universitas Pendidikan Indonesia.

Syahyuti (2007).Konsep dan Strategi Pendekatan Kultural dalam Pembangunan Pertanian: Studi Kasus Pembangunan Pertanian di Thailand. [Online]. Tersedia: http://www.geocities.com/ $s \quad y \quad a \quad h \quad y \quad u \quad t \quad i \quad /$ Pendekatankultural_pembangunanpertanian.pdf

Timmons, J. \& Spinelli, S. (2007) New Venture Creation, Entrepreneurship for the 21st Century. New York: McGraw-Hill. 